\title{
OECDpublishing
}

AGRICULTURAL MARKET ACTIVITY AND BOKO HARAM ATTACKS IN NORTHEASTERN NIGERIA

WEST AFRICAN PAPERS

September 2017 No. 09

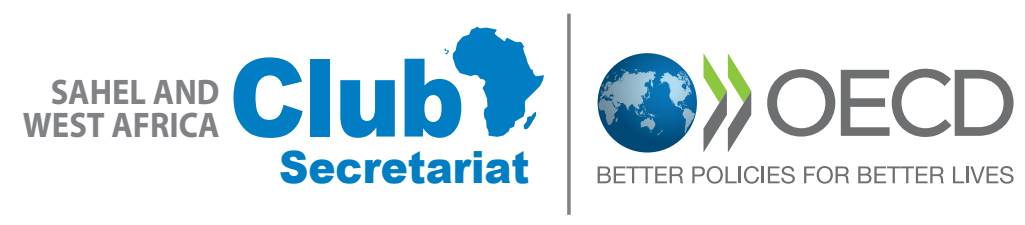





\section{AGRICULTURAL MARKET ACTIVITY AND BOKO HARAM ATTACKS IN NORTHEASTERN NIGERIA}

This paper has been prepared by

JAMON VAN DEN HOEK

OREGON STATE UNIVERSITY 


\section{WEST AFRICAN PAPERS}

The West African Papers series explores African socio-economic, political and security dynamics from a regional and multidisciplinary perspective. It seeks to stimulate discussion and gather information to better anticipate the changes that will shape future policies. The series is designed for a wide audience of specialists, development practitioners, decision makers and the informed public. Papers are available in English and/or French, and summaries are available in both languages. Initiated by the Sahel and West Africa Club (SWAC) to highlight and promote West African issues, the work presented is prepared by its Secretariat, Members and partners, other OECD departments, related international organisations, associated experts and researchers.

For more information on the Sahel and West Africa Club: http://www.oecd.org/swac.

Please cite this publication as:

Van Den Hoek, J. (2017), "Agricultural market activity and Boko Haram attacks in northeastern Nigeria", West African Papers, N09, OECD Publishing, Paris.

http://dx.doi.org/10.1787/13ba9f2e-en

Author contact: vandenhj@oregonstate.edu

ISSN 2414-2026

OECD Working Papers should not be reported as representing the official views of the OECD or of its member countries. The opinions expressed and arguments employed are those of the authors.

This document and any map included herein are without prejudice to the status of or sovereignty over any territory, to the delimitation of international frontiers and boundaries and to the name of any territory, city or area.

Working Papers describe preliminary results or research in progress by the author(s) and are published to stimulate discussion on a broad range of issues on which the OECD works. Comments on Working Papers are welcomed, and may be sent to the Sahel and West Africa Club, OECD, 2 rue André-Pascal, 75775 Paris Cedex 16, France.

Authorised for publication by Laurent Bossard, Director, Sahel and West Africa Club Secretariat (SWAC/OECD).

(C) OECD 2017

You can copy, download or print OECD content for your own use, and you can include excerpts from OECD publications databases and multimedia products in your own documents, presentations, blogs, websites and teaching materials, provided that suitable acknowledgment of OECD as source and copyright owner is given. All requests for commercial use and translation rights should be submitted to rights@oecd.org. 


\begin{abstract}
This paper examines the linkages between Boko Haram activities in northeastern Nigeria and declined activities in regional agricultural markets. Building on data from both the Armed Conflict Location and Event Data Project (ACLED) and the Famine Early Warning Systems Network (FEWS NET), the paper first considers the geographic distribution of Boko Haram events with respect to market towns and discusses whether there is evidence of Boko Haram activities near markets having influence on declined market operations. Next, it examines the temporal character of market operations and the timing of their changes in their operational status, including market closures, with respect to the seasonality of agricultural production and land use in northeastern Nigeria. The paper measures the frequency of changes in regional market activities and considers spatial relationships and temporal correlations with Boko Haram activities in the region over twelve periods from late 2014 through the end of 2016. Finally, the paper formulates policy recommendations for assessing and mitigating coupled challenges of human and environmental security.
\end{abstract}

Keywords: markets, political violence, Boko Haram, northeastern Nigeria, Lake Chad JEL Classification: D74, H56, N47, N57, R11

\begin{abstract}
ABOUT THE AUTHOR
Jamon Van Den Hoek is Assistant Professor of Geography at Oregon State University. He pursues satellite imagery and machine learning approaches to document changing social-environmental relationships, and is particularly interested in gauging the linkages between land cover change and violent social conflict.
\end{abstract}

\title{
NOTE TO READERS
}

This note is published as part of the partnership between SWAC/OECD and the Sahel Research Group of the University of Florida. The collaboration aims to: 1. Reinforce ties between research and policies for sustainable development that can help better anticipate changes within the Sahel and West Africa Region; 2. Promote West African expertise by reinforcing the links with African researchers and research centres through the Sahel Research Group network. 
TABLE OF CONTENTS

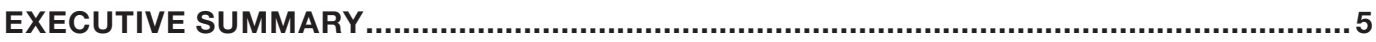

MARKETS AND POLITICAL VIOLENCE IN NORTHEASTERN NIGERIA ............................5

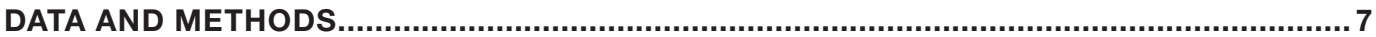

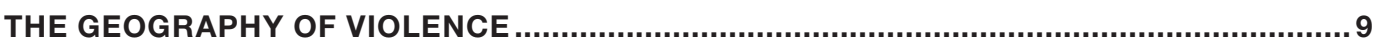

BOKO HARAM EVENTS AND MARKET ACTIVITY TIMELINES ........................................ 10

BOKO HARAM EVENTS AND MARKET ACTIVITY DECLINE .......................................... 12

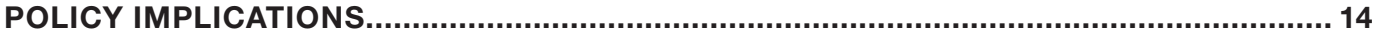

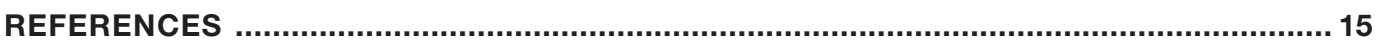

\section{FIGURES}

Figure 1. Timeline of Boko Haram events and associated fatalities with periods of regular market activity reporting shown in green, 2009-16

Figure 2. Average vegetative condition for each month and number of Boko Haram events over Borno State, 2000-16

Figure 3. Market activity, December 2014-November 2016

Figure 4. Linear regression between the number of Boko Haram events in the period preceding a FEWS NET report and the number of markets with declined, stable or improved activity .....

\section{MAPS}

Map 1. Geographic distribution of markets in northeastern Nigeria................................7

Map 2. Geographic distribution of Boko Haram-related events, market attacks, and market locations, December 2014 - November 2016

Map 3. Geographic distribution of declined market activity with Boko Haram events, December 2014 - November 2016 


\title{
EXECUTIVE SUMMARY
}

$\mathbf{T}$ his paper examines the consequences of violence on regional socio-economic processes by assessing the linkages between Boko Haram activities in northeastern Nigeria and declined activities in regional agricultural markets. The relationships of both Boko Haram events and market activities are examined through temporal and spatial lenses. While Boko Haram has not formally expressed a strategy for disrupting regional agricultural production or market operations, markets are prime venues for targeting civilians and have seen 38 direct attacks between November 2014 and December 2016 at a rate of one market attack every 18 days. Similarly, Boko Haram attacks are well timed to disrupt agricultural production with the peak period of attacks immediately preceding the lean season and then reaching a secondary peak just at the harvest's conclusion; both seem almost designed to deter agricultural labour as well as the transport of agricultural goods to market. In part because of such attacks, no more than $35 \%$ of markets have shown normal activity at any period since November 2014, which is characteristic of the rather anaemic market system in the Lake Chad region.

Importantly, the vast majority of markets that have seen a decline in activities were not directly attacked but may have been affected due to an implicit or perceived threat of violence, as well as regional population displacement or reduced agricultural production, all of which have been linked to Boko Haram activities. Finally, there is a strong positive correlation between the frequency of Boko Haram attacks and a decline in market activity as well as an even stronger negative correlation between attack frequency and market stability. The targeting of civilians and suicide bombings orchestrated by Boko Haram are not responsible for all of these changes in market activity, however, the direct and indirect effects of such activities have clear consequences for market conditions as well as for regional security.

The paper first considers the geographic distribution of Boko Haram events with respect to market towns and discusses whether there is evidence of Boko Haram activities near markets having influence on declined market operations. Next, it examines the temporal character of market operations and the timing of changes in their operational status, including market closures, with respect to the seasonality of agricultural production and land use in northeastern Nigeria. The paper then measures the frequency of changes in regional market activities and considers the spatial relationships with Boko Haram events. It then measures the correlation between changes in market operations and Boko Haram activities in the region over twelve periods from late 2014 through the end of 2016 and, finally, formulates policy recommendations for assessing and mitigating the coupled challenges of human and environmental security.

\section{MARKETS AND POLITICAL VIOLENCE IN NORTHEASTERN NIGERIA}

\begin{abstract}
O ver the last eight years, the deepening humanitarian crisis in the Lake Chad region of West Africa has upset the lives and livelihoods of millions of people. At the shared border of Cameroon, Chad, Niger, and Nigeria, the confluence of drought, food insecurity, conflict, displacement, and long-standing historical socio-economic inequality and marginalisation have resulted in profound vulnerabilities for communities in the region. Such intersectional vulnerabilities are not unique to Lake Chad communities but are particularly pronounced given extreme regional poverty and reliance on subsistencebased rainfed agricultural production with characteristically low productivity (FEWS NET, 2017c; FAO, 2017), which together yield less resilience to enviro-climatic and sociopolitical disruptions, such as droughts and conflicts.
\end{abstract}

Borno and Yobe States in northeastern Nigeria have seen intermittent periods of critical acute food insecurity since January 2014 with Adamawa State experiencing acute food 
insecurity (Emmanuelar, 2015; FEWS NET, 2017c). As of May 2017, 5.2 million people in these three states were food insecure (WFP, 2017) and in 2016, 30\% of children under five years of age experienced acute malnutrition (Skinner and Begum, 2016). There is also evidence of famine in two Borno towns, Bami and Banki, where upwards of two thousand people may have died between January and September 2016 (FEWS NET, 2016). The lean season, defined as the period during which food supplies from the previous harvest have largely been consumed, typically begins in July. In 2017, however, the lean season began in May and will likely contribute to a protraction of severe food insecurity until at least fall 2017 (Skinner and Begum, 2016; OCHA, 2017).

While a long history of environmental and political conditions underpins regional food insecurity (Watts, 2013), its current depth, duration, and geographic distribution are recognised as being driven by Boko Haram violence. Borno in northeastern Nigeria has been the epicentre of this violence, witnessing over $54 \%$ of Boko Haram related events since the first attack in July 2009. Since then, over 30000 fatalities were recorded in the Armed Conflict Location and Event Data Project (ACLED) through the end of 2016, a staggering loss of life that has given Nigeria the unfortunate claim of having the highest civilian casualty rate in the world (Skinner and Begum, 2016). Recent survey and interview data collection of 1500 internally displaced persons (IDPs) in Borno State found that 85\% of respondents identified the Boko Haram insurgency as having increased food insecurity (Emmanuelar, 2015). Such violence contributes to regional food insecurity by inhibiting agricultural production in various ways including through the restriction of physical access to farms by Boko Haram, the regional paramilitary, or the state military (Skinner and Begum, 2016; Martin, 2016); delaying or reducing planting or harvesting, which impinges on yield and quality of food (Eme et al. 2014); as well as forcing the abandonment of fields due to the perception or direct threat of violence (Awodola and Oboshi, 2015).

Given a reduction in agricultural stock, the regional market operations that support the trade and sale of agricultural goods such as millet, cowpea, sorghum, and maize as well as livestock and fish have also declined. In response to direct Boko Haram violence, market operations are at times shuttered by the military, sometimes permanently (Martin, 2016); transportation routes are closed or avoided, choking the flow of supplies into or from markets (Awodola and Oboshi, 2015; Ogbozor, 2016); and traders and patrons sometimes simply disregard markets that are considered unsafe (Ogbozor, 2016). Such changes have had cascading effects, dwindling market volume even during immediate post-harvest periods and increasing the prices of commodities, including many staple foods (FEWS NET, 2017a, 2017b). As markets such as those in Maiduguri, the central market town in Borno State, source grain and other goods to Cameroon, Chad, Niger, and the broader Sahel, the consequences of declined market operations have externalised (Ogbozor, 2016; Guilbert, 2016), effectively expanding the indirect effect of Boko Haram violence across the broader region.

Boko Haram attacks between 2000 and 2015 were characterised by a campaign of violence against civilians (Dowd and Drury, 2017), increasing in both frequency and fatality, with activities waning in 2016. While the group has not formally expressed a strategy to disrupt regional agricultural production or market operations, markets are prime venues for targeting civilians and have seen numerous direct attacks (Awodola and Oboshi, 2015). Though considerable and vital information has been collected on the destruction of towns, the murder of civilians, and the movements of nearly 1.9 million IDPs in northeastern Nigeria as of April 2017 (DTM, 2017), the place-based relationships linking Boko Haram activities and changes to regional market operations have never been formally assessed. Indeed, conflict processes and attendant patterns of social, economic, and environmental changes are often data-rich yet elusive in their information scarcity. The specific manners and interactions by which violent conflicts may have spatially diffused consequences across the landscape is difficult to consistently monitor in an area as broad as the Lake Chad region. 


\section{DATA AND METHODS}

M arket activities are based on a series of twelve reports produced by the Famine Early Warning Systems Network (FEWS NET) that leverage data collected through field-based investigations and georeferenced, time-stamped market activity (i.e. operational status) across the region. Markets are predominantly located in northeastern Nigeria with additional coverage in Cameroon, Chad, and Niger (Map 1).

Map 1

Geographic distribution of markets in northeastern Nigeria

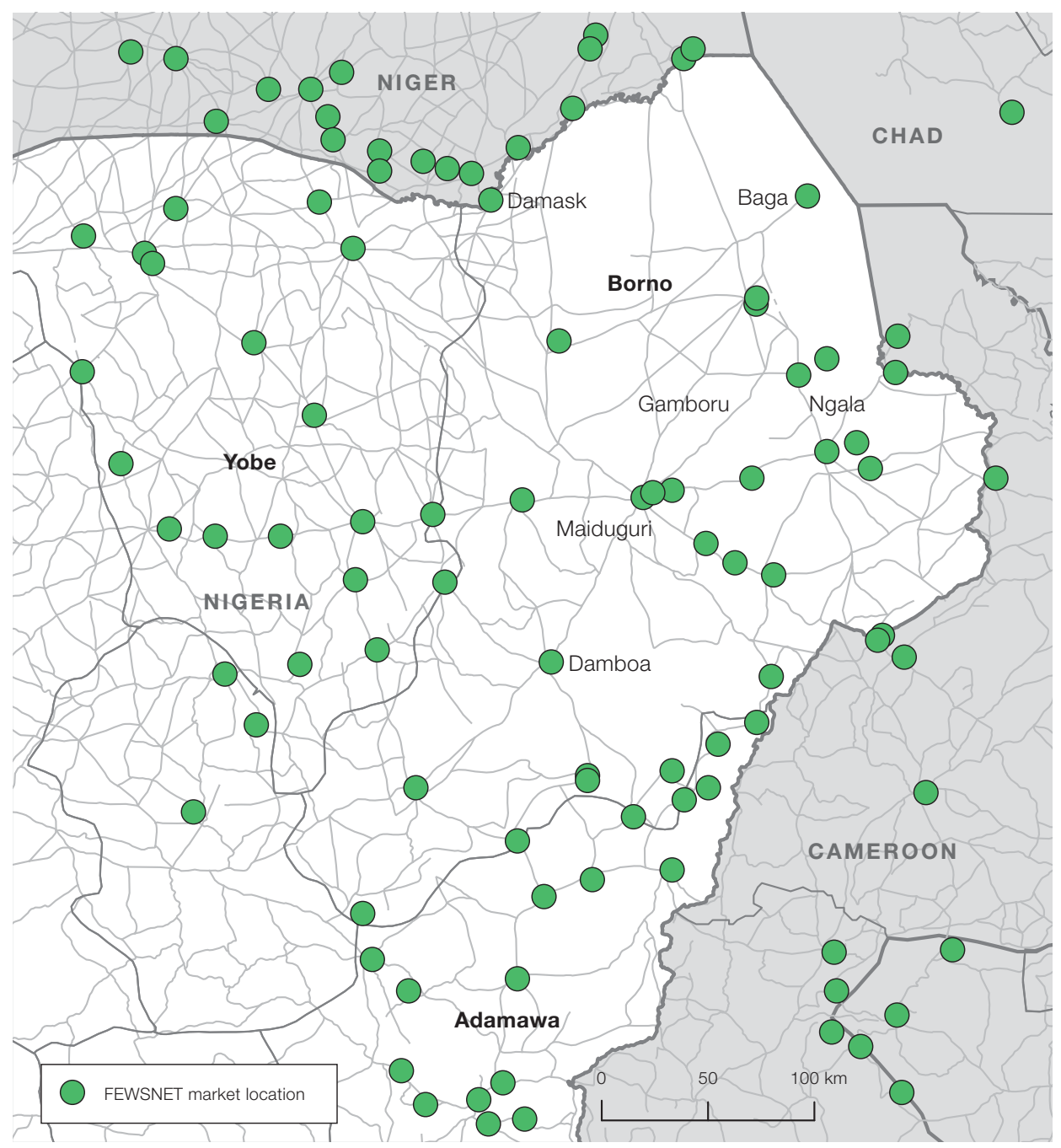

Note: 99 of the 112 markets included in FEWS NET market activity reports are shown here. The regional road network based on OpenStreetMap and internal administrative boundaries based on the GADM database of Global Administrative Areas, are displayed in the background.

Sources: FEWS NET, 2017d; OpenStreetMap (Haklay and Weber, 2008) and GADM database of Global Administrative Areas, version 2.0, http//www.gadm.org.

The earliest publicly available market activity report was produced in January 2015 and focused on activities in December 2014, which coincided with a relatively intense period of Boko Haram attacks. Since then, reports have been generated through November 2016, typically every one to two months, with a notable 8-month gap in coverage between October 2015 and June 2016. Market activities are categorised through qualitative means into four ordinal levels of activity that slightly vary before and after the April 2015 report:

1. Normal activity/operating normally

2. Some disruption, reduced activity/operating slightly below normal 
3. Significant disruption, limited activity/operating well below normal

4. Minimal or no activity/not operating

For the purposes of this note, levels 2 and 3 have been merged into a single "reduced or limited activity" status, and an additional value of "no data" has been added given that the first two market reports only include 66 and 87 of the 112 markets under consideration. While the change in market activities in part reflects the spatial diffusion of indirect conflict, the manner of response and the spatial relationships therein are less apparent.

Georeferenced Boko Haram event data were collected using the $7^{\text {th }}$ version of the ACLED dataset, which covers conflict events on the African continent from 1997-2016 (Raleigh et al., 2010). All conflict events involving Boko Haram as actors or allies were considered in this paper, yielding a total of 2429 conflict events spanning 26 July 2009 to 26 November 2016. In total, 1812 events were fatal, resulting in 30516 fatalities associated with Boko Haram. All events involving Boko Haram, rather than just those events in which Boko Haram was the aggressor, are included here since such non-aggressor events reflect the geography of Boko Haram activities and may influence the ways in which civilians make decisions in response to such events.

The incidence of fatal events peaked in early 2015 when 6071 fatalities (nearly 20\% of total fatalities) were recorded within a two-month window between January and February (Figure 1). The specific timing and geographic distribution of Boko Haram activities have often come in response to state or paramilitary offensives. However, such "responses" have typically been characterised by the deliberate targeting of civilians (Dowd and Drury, 2017). Indeed, 900 conflict events (37\%) were coded as violence against civilians, 934 events (38\%) were coded as battles in which no change of territory occurred, while the remaining 595 events (25\%) were largely distributed between battles with change in territorial control, remote violence, and strategic development, which refers to events that are relevant to the conflict but which do not involve active fighting.

\section{Figure 1}

Timeline of Boko Haram events and associated fatalities with periods of regular market activity reporting shown in green, 2009-16

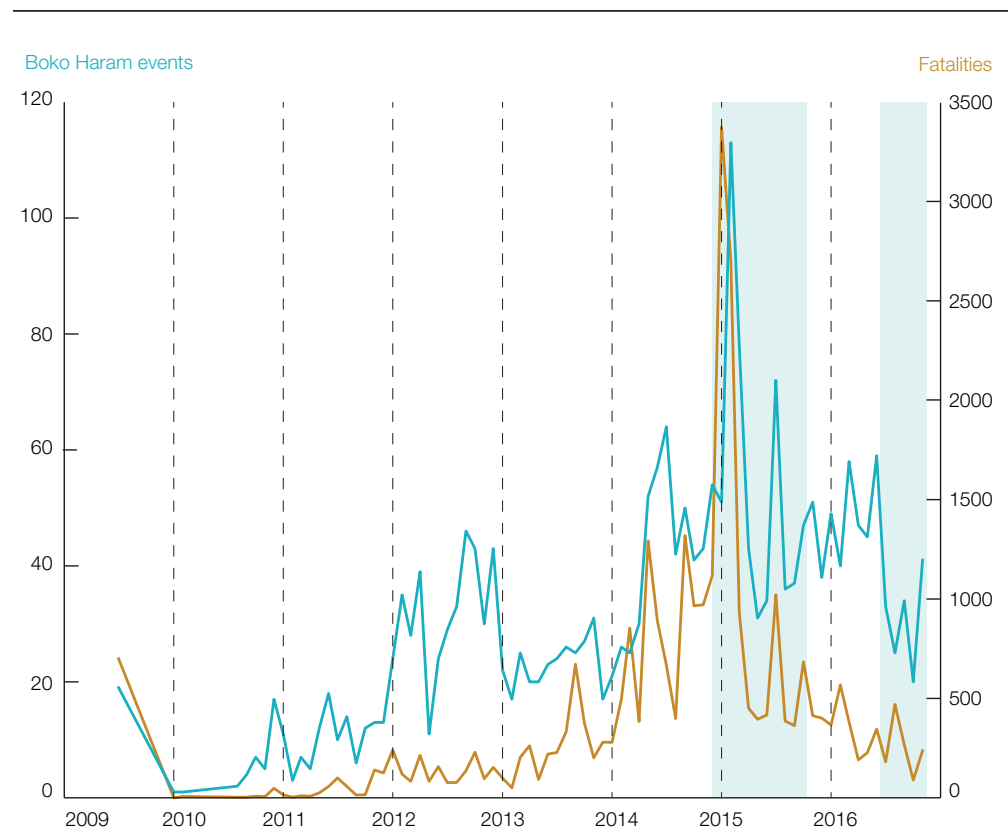

Sources: ACLED, 2017; FEWS NET, 2017d and author's calculations

The spatially-explicit relationship between changing market activity and Boko Haram incidents is visible through five spatial typologies of market-event relationships:

1. A market is directly targeted by Boko Haram.

2. A market is located in a town that is itself a hotspot of Boko Haram attacks or violence. 
3. A market is located on a trade route that has experienced disruption of activity, which subsequently affects the transportation of goods into market.

4. A market is surrounded by or otherwise spatially proximate to locations of Boko Haram attacks.

5. A market is relatively distant from a Boko Haram attack yet may show declined activity for a range of site-specific reasons.

While it is impossible to diagnose the specific reasons for a change in market activities without widespread field interviews or survey data, change may result from the indirect effects of Boko Haram violence, which include internal displacement, agricultural land abandonment, or military closure of the market given security concerns.

\section{THE GEOGRAPHY OF VIOLENCE}

$\mathrm{T}$ here were 15865 fatalities associated with Boko Haram activities during the FEWS NET market monitoring period of December 2014 to November 2016. As Boko Haram's targeting of civilians is made clear in the ACLED dataset, this focus is also reflected in the geographic proximity between locations of Boko Haram violence and regional markets (Map 2).

Map 2

Geographic distribution of Boko Haram-related events, market attacks and market locations, December 2014 - November 2016

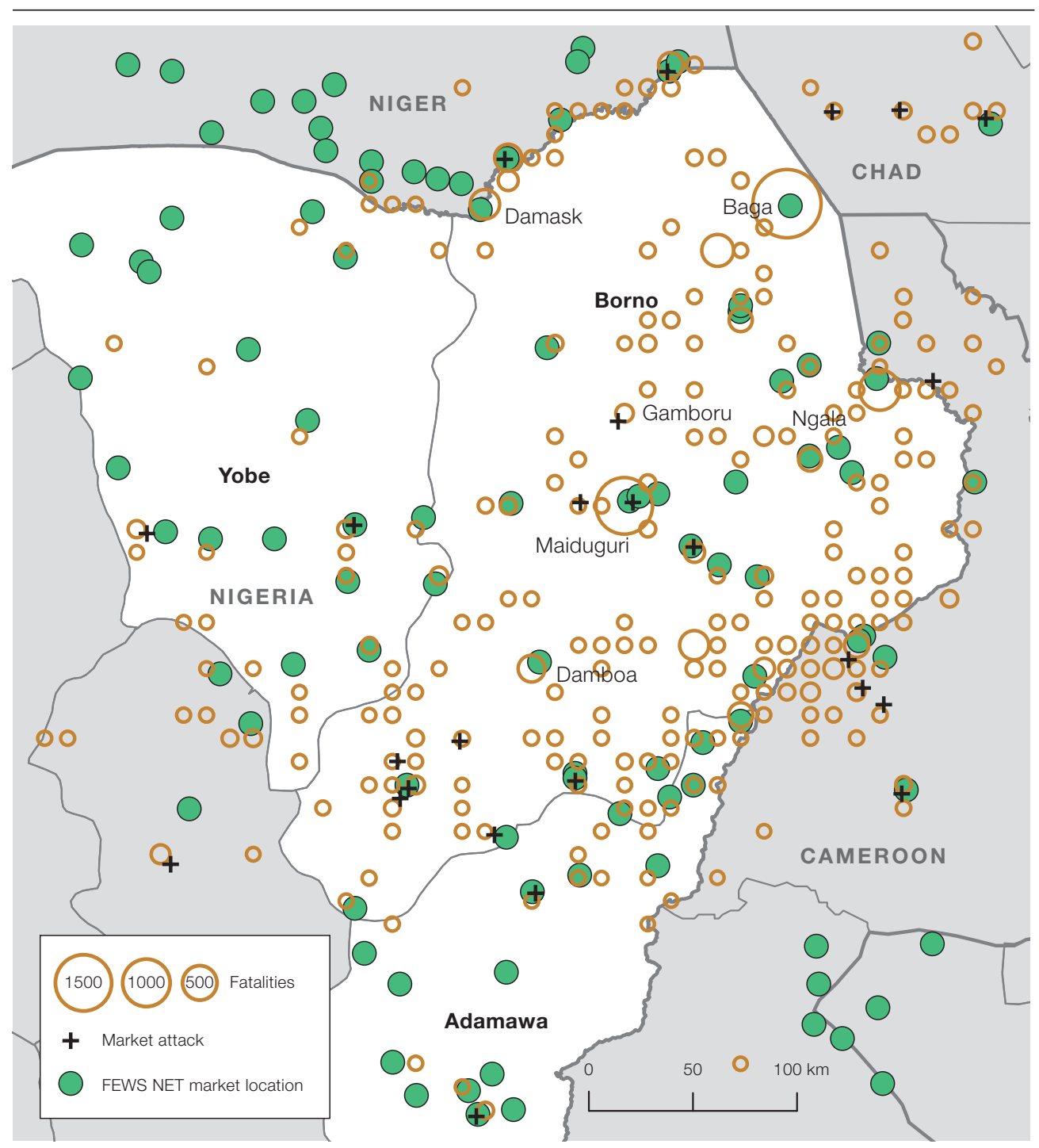

Note: Boko Haram symbols are scaled by the total number of fatalities recorded in each $1 / 10^{\text {th }}$ degree cell. Sources: ACLED, 2017; FEWS NET and author's calculations 
As was the case before FEWS NET market monitoring began, Boko Haram violence has primarily been in Borno State but has also regularly occurred along the BornoNiger border and in Cameroon. A disproportionate number of attacks have occurred in Maiduguri in central Borno and in Baga near the state's northeast border with Chad. The focus on these cities is unsurprising given that Maiduguri is the central market for regional and international trade, nominally receiving agricultural products from across Borno and neighbouring states, and Baga is the regional fish market located on the shores of the receding Lake Chad. Maiduguri and Baga suffered 1414 and 1751 fatalities, respectively, during the two-year monitoring period with the remaining fatalities distributed across the region in lower densities. It should be noted that the cumulative density and geographic distribution of events broadly agrees with those of the fatalities, in that locations with frequent Boko Haram attacks experience high fatalities.

Of special note, there are 38 recorded events at or near markets in 29 locations during the FEWS NET monitoring period, and these attacks caused 663 deaths. Maiduguri was the clear focal point for market attacks, six of which took place in Maiduguri's markets alone, killing a total of 193 people. Boko Haram events at or near markets were a consistent presence, taking place on average every 18 days during nearly every month from November 2014 through February 2016 followed by a pause in activities until October 2016 when a single event took place. Boko Haram market attacks were distributed across the region with most (15) occurring within Borno. Seventeen markets were directly attacked by Boko Haram but were not included in the FEWS NET assessment of market activity. The vast majority (31) of the events were suicide-bombing attacks, as is common with Boko Haram, and nearly all consisted of violence targeted at civilians. Market attacks wounded at least 771 people, though this figure is likely higher as the number of those wounded was often reported in vague terms.

\title{
BOKO HARAM EVENTS AND MARKET ACTIVITY TIMELINES
}

\begin{abstract}
A lthough Boko Haram has not formally expressed a strategy concerning the control A or influence of agricultural production, the group's pattern of monthly activities nonetheless aligns with critical periods of the agricultural land-use calendar for northern Nigeria (Figure 2). In particular, the month with the greatest frequency of attacks (June) immediately precedes the lean season, potentially indicating a strategy of resource allocation in anticipation of the pending lean season. In August and September, rainfed agriculture is at a peak, followed by the annual harvest in September and October as the rainy season concludes. In November, midway through the harvest, when the lean season has typically passed, the incidence of Boko Haram events increases to 220 per month, contributing to an atmosphere of insecurity for farmers and labourers when more time is required outdoors to complete the harvest. The rate of Boko Haram events rises again in February to over 230 events per month as the final harvests take place, which, similarly, may serve as a deterrent for transporting agricultural commodities and staples into regional markets.
\end{abstract}

Though not directly related to market operations, such seasonal dynamics inform the interpretation of changing market conditions based on FEWS NET reports. On the whole, the 112 regional markets show improved operational status from 2014-16 despite monthly attacks by Boko Haram (Figure 3). No more than 35\% of markets expressed normal activity at any period of data collection, however. With the exception of the first two report dates, over half of the markets show reduced or limited activity throughout the study period. At the outset of data collection in December 2014, 46 markets, mainly those in Niger and Cameroon, were not included but by the second assessment in February 2015, the markets in Cameroon were incorporated into the data collection. These markets generally had normal activity, and by the March 2015 assessment, coverage had expanded to include markets in Niger and Chad. Thus, the relative lack of data early in the data collection period reflects the smaller scale of initial market data collection rather than a lack of physical access to markets resulting from Boko Haram violence or perceived threats thereof. 
Figure 2

Average vegetative condition for each month and number of Boko Haram events over Borno State, 2000-16

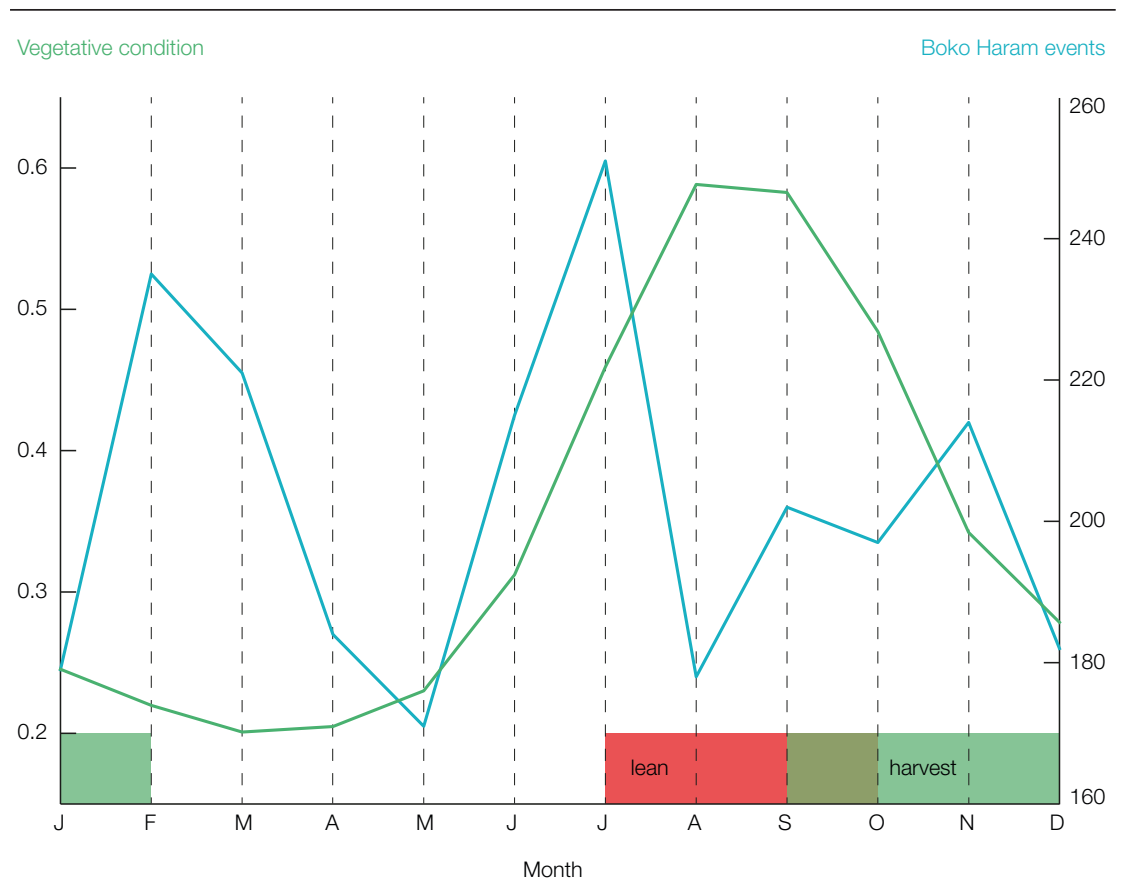

Note: The monthly frequency of Boko Haram events is derived from 2009-16 ACLED data. Vegetative condition is based on the average Normalized Vegetative Difference Index (NDVI) value across Borno as measured by the Moderate Resolution Imaging Spectroradiometer (MODIS) sensor on board NASA Terra and Aqua satellites. The months corresponding to the lean and harvest periods are also indicated.

Source: ACLED, 2017 and author's calculations

\section{Figure 3}

Market activity, December 2014-November 2016

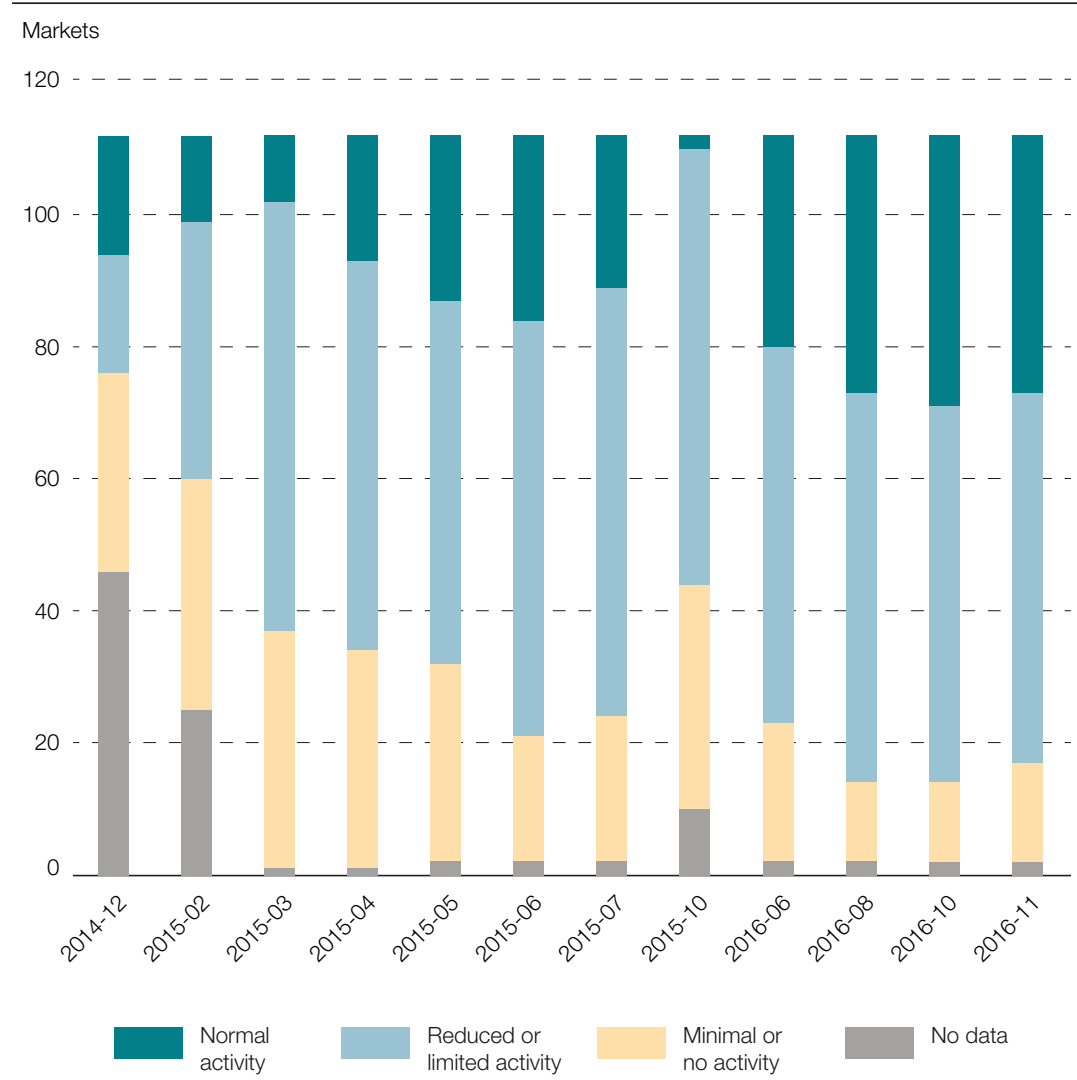

Sources: FEWS NET, 2017d and author's calculations 
Late 2015 presented a tipping point in market operational status. In October 2015, only two markets showed normal activity, 10 markets lacked data, and 66 markets show reduced or limited activity. This decline in market operations deviates notably from the relative improvement in market activity that began in March 2015 and follows a period of more than six thousand recorded fatalities between January and February 2015. Market operations improved from April to June 2015, as the number of markets with minimal or no activity were nearly halved and there was a general decline in the frequency of Boko Haram attacks. The slight reduction of markets showing normal activity in July 2015 is surprisingly muted given the doubled increase in violence between June and July with 417 and 1021 fatalities, respectively.

By October 2015, the Nigerian government began recommending that some markets close for fear of attracting attacks by Boko Haram (FEWS NET, 2015). This decision directly contributed to an increase in the number of markets with minimal or no activity. Unfortunately, the eight-month period between the October 2015 report and the June 2016 report does not allow for an examination of whether the decline in market operations observed in October resulted from the delayed season onset or the subsequent delay of the staple cereal harvest, which only began in September/October (FEWS NET, 2015). Nonetheless, the relative improvement in market status operations continued from August through November 2016 as 39 markets showed normal activity, the largest number of the entire study. Similarly, markets showing minimal or no activity declined to a count of 12 to 15 in the waning months of 2016. Much of this recovery is attributed to the concomitant decline in Boko Haram events, which in turn allowed increased trade flows to and from markets (WFP, 2017).

\section{BOKO HARAM EVENTS AND MARKET ACTIVITY DECLINE}

M arkets with declined activity located relatively far from attack locations may nonetheless have been affected by an implicit or perceived threat of violence, regional population displacement, reduced agricultural production, delayed harvest season, or other socio-environmental or livelihood-related factors. In order to examine these relationships, the frequency of decline in market operational status, e.g., a change from reduced or limited to minimal or no activity, was recorded for each market (Map 3). The frequency of decline was selected given its relative value as reflecting a temporally acute shock, be it induced by conflict, displacement, drought, or harvest shortage. Markets within Adamawa, Borno, and Yobe bore the brunt of declined operations while markets in Niger showed broad improved operations over the period of data collection. Only four markets maintained a stable status across all time periods, and the same four markets had minimal or no activity. These four markets are located within 50 kilometres of one another in eastern Borno between the large market towns of Maiduguri and Gamboro Ngala.

A notable limitation of this assessment is the lack of information related to the transport of specific goods between markets and even across national borders. Such information would inform a better understanding of how economic factors and cross-border trade may manifest a geographic pattern of demand, which would, in turn, help understand why certain markets may have more demand-driven resilience than others. Very little is also known about variations across markets in terms of market-specific prices and the relative proportion of foodstuffs and other agricultural products within and between markets. Such information would be helpful in understanding if and to what extent local demand for given agricultural products contributes towards a greater degree of resilience to the effects of Boko Haram-related violence.

To provide a temporally explicit perspective on the relationship between Boko Haram event occurrence and market activity decline, the number of Boko Haram attacks that occurred in the one to two-month period between market activity data collection were regressed 
$\underline{\text { Map } 3}$

Geographic distribution of declined market activity with Boko Haram events, December 2014 - November 2016

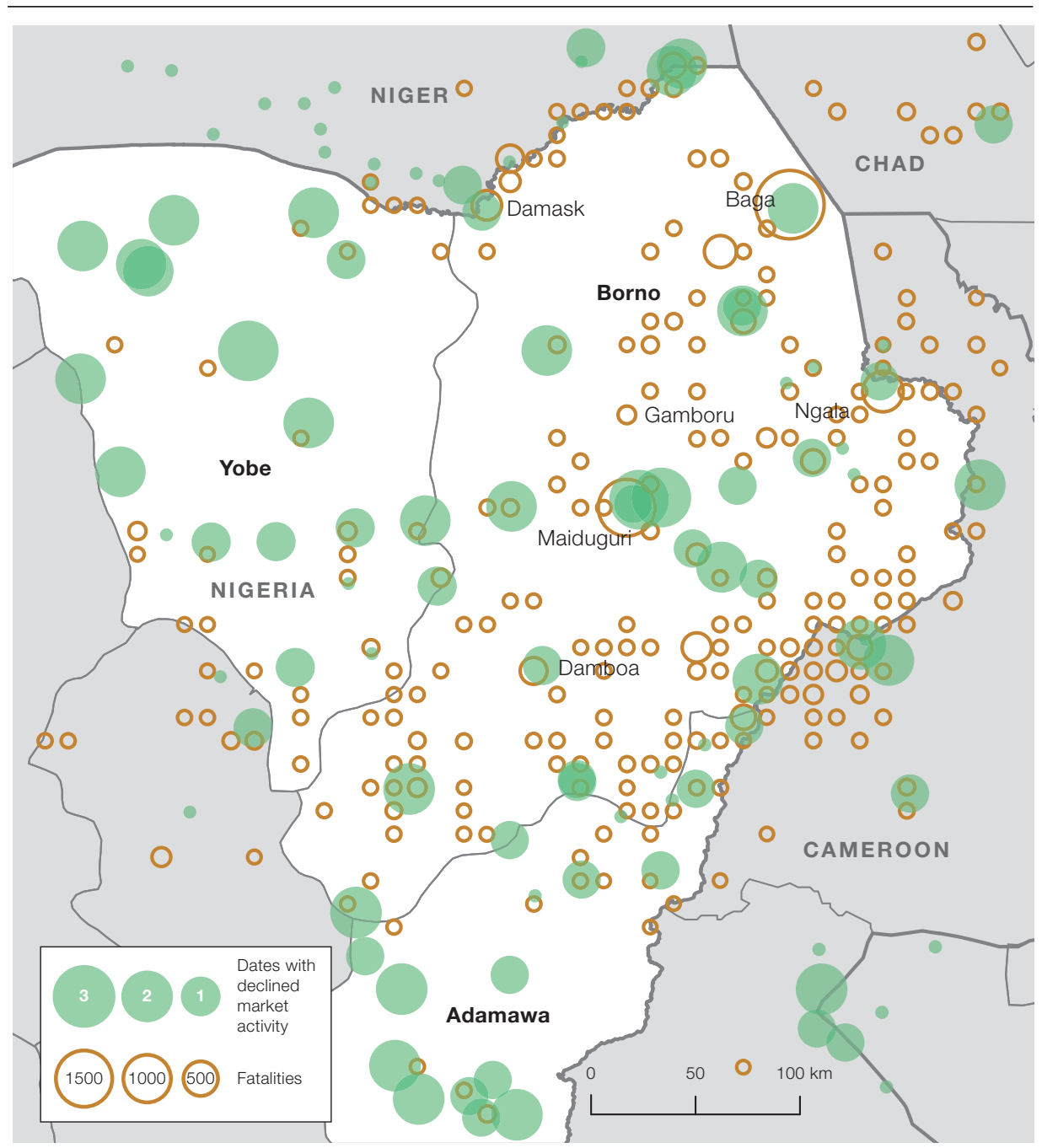

Sources: ACLED, 2017; FEWS NET, 2017d and author's calculations

with the number of markets that expressed declined activity on the subsequent date of observation (Figure 4a) as well as those markets that showed stable or improved activity (Figure 4b). As expected, there is a positive correlation between the frequency of Boko Haram events during a given period and decreased market activities. Furthermore, there is a stronger relationship between the frequency of Boko Haram events and markets that saw only a reduction in activity ( $\mathrm{r}=0.77$, Root Mean Square Error=3.9) versus markets that saw a cessation of activity ( $r=0.44, \mathrm{RMSE}=4.28)$. There is an even stronger linear relationship between Boko Haram events and markets that show stable or improved activity $(r=0.83)$ though this relationship is inverted with increasing frequency of events leading to a reduced number of markets with stable or improved activity. Such relationships do not suggest direct causality but do identify a consistency between Boko Haram activities and market operations over time. Moreover, there are caveats to interpreting such relationships, one of which being that some Boko Haram attacks closely followed military operations against Boko Haram and that such military operations often resulted in large-scale civilian casualties (Dowd and Drury, 2017). This suggests a potential collinearity between Boko Haram attacks and military responses during some periods. 
Figure 4

Linear regression between the number of Boko Haram events in the period preceding a FEWS NET report and the number of markets with declined, stable or improved activity

\section{a) Markets with declined activity}

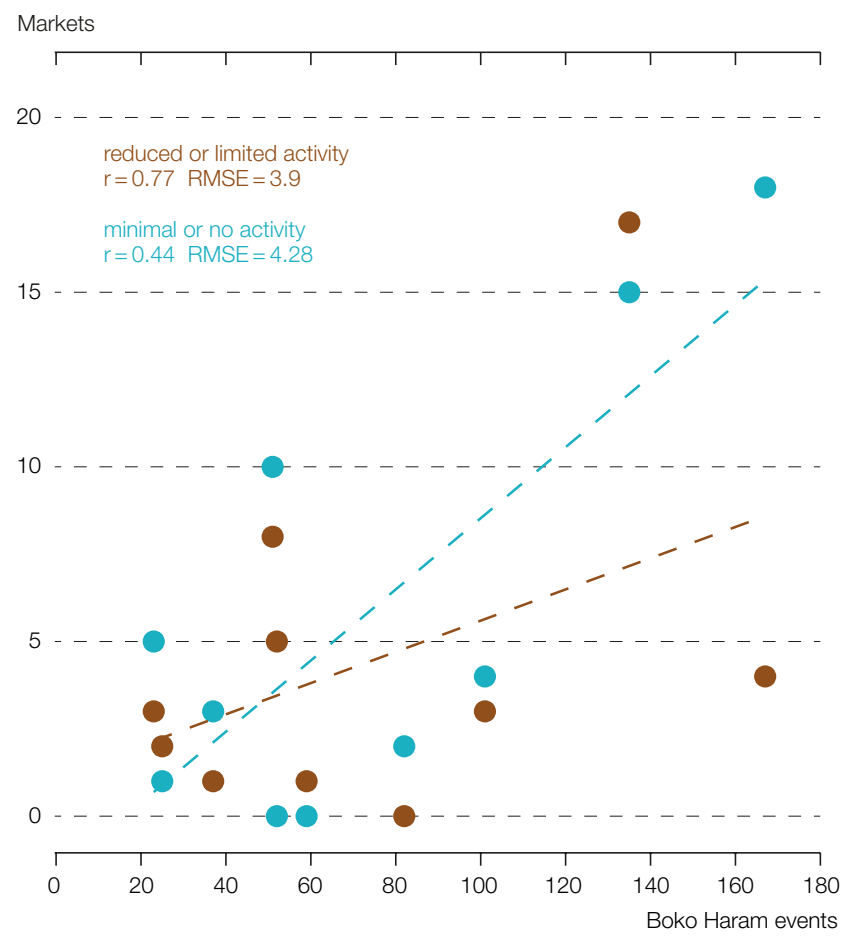

\section{b) Markets with stable or improved activity}

Markets
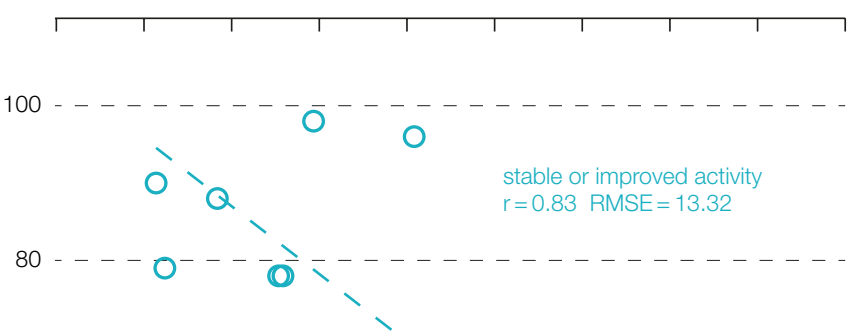

60

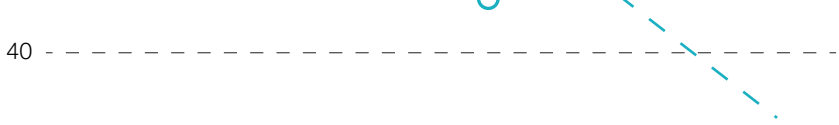

20

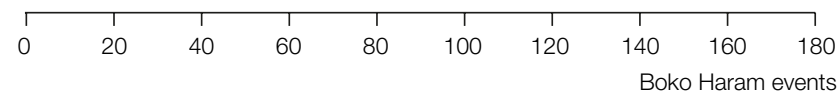

Note: relationships spanning the 8-month period between the October 2015 and June 2016 market activity reports were excluded from consideration, leaving 11 periods.

Sources: ACLED, 2017; FEWS NET, 2017d and author's calculations

\section{POLICY IMPLICATIONS}

Th paper provides the foundation for an integrated security assessment framework

that would incorporate real-time data on drought, migration and displacement, and conflict incidence in order to identify hotspots of exceptionally vulnerable populations. By recognising the inter-linkages between such processes, the framework would advocate for a balance between government and civilian security measures, socio-economic stabilisation and development during conflict periods. It would further support peacebuilding and post-conflict transformation which, in Nigeria, would be greatly enabled by addressing the long-standing regional disparities in intra-regional wealth and livelihood opportunities.

Given the relationship between agricultural production and conflict shown in this paper as well as recent findings that show that periods of drought correspond to increased violence against civilians by upwards of 40\% (Bagozzi et al., 2017), it is paramount to support both human and environmental security through the development of resilience to localised drought effects. Monitoring groups like FEWS NET have made exceptional strides towards developing spatially-detailed data on agricultural productivity that inform sustainable and resilient agricultural land use. As a complement to these efforts, the design and implementation of a regional drought insurance programme that adopts a FEWS NET-style early warning system to support preventative actions in vulnerable communities would be most valuable. The incorporation of drought insurance would not only benefit those most vulnerable to near-term drought, but would also likely reduce the potential for and magnitude of drought-related violence. 
With nearly 1.9 million IDPs in northeastern Nigeria (DTM, 2017) and the potential for large-scale regional displacement in the future, pathways that guide and even encourage displacement should be made secure and identifiable (i.e., mapped) by government authorities. The development of such pathways would serve to recognise that fleeing the site of violence is typically an informed, strategic decision that has short- and long-term benefits for the individual and the state. Having access to these pathways would not only support the decision-making process of vulnerable populations in conflict regions, it would also enable near real-time monitoring and improved security of population circulation within and between regions, and would provide planning information for potential host communities.

The results of this paper indicate the value of using complementary open-access georeferenced datasets to evaluate the sometimes spatially diffuse consequences of violence on regional socio-economic processes. Combining ACLED micro-level data on Boko Haram event incidence and distribution and FEWS NET-reported market activities proved interesting. The results of this study echo the anecdotal information collected through interview and survey data that show that the agricultural sector was the most affected by Boko Haram activities (Awodola and Oboshi, 2015). It also shows that there is a direct, observable relationship between the timing of Boko Haram activities and market activity decline. A deeper examination of how Boko Haram's indirect influence over market activities may effectively serve to extend Boko Haram's area of influence beyond its physical territorial control, would be a welcome extension of this study, as would a more developed understanding of the ways in which regional markets may potentially offer livelihood-resilience despite protracted violence against civilians.

\section{REFERENCES}

ACLED (2017), "Armed Conflict Location and Event Data. Africa Data, version 7", available at: www.acleddata.com/data/acled-version-7-1997-2016.

Awodola, B. and A. Oboshi (2015), "Terrorism in Northern Nigeria: A Threat to Food Security in Maiduguri", Mediterranean Journal of Social Sciences, Vol. 6/352, pp. 11-17.

Bagozzi, B.E., O. Koren and B. Mukherjee (2017), "Droughts, Land Appropriation and Rebel Violence in the Developing World", The Journal of Politics, Vol. 79/3, pp. 1057-1072.

Dilley, M. and T.E. Boudreau (2001), "Coming to terms with vulnerability: a critique of the food security definition", Food policy, Vol. 26/3, pp. 229-247.

Dowd, C. and A. Drury (2017), "Marginalisation, insurgency and civilian insecurity: Boko Haram and the Lord's Resistance Army”, Peacebuilding, Vol 5/2, pp. 136-152.

DTM (Displacement Tracking Matrix) (2017), "Nigeria”, available at: www.globaldtm.info/nigeria/ [29 June 2017].

Eme, O.I., T. Onyishi, O.A. Uche and I.B. Uche (2014), "Challenges of food security in Nigeria: Options before government", Oman Chapter of Arabian Journal of Business and Management Review, Vol. 4/1, pp. 15-25.

Emmanuelar, I. (2015), "Insurgency and humanitarian crises in Northern Nigeria: The case of Boko Haram", African Journal of Political Science and International Relations, Vol. 9/7, p. 284.

FAO (Food and Agriculture Organization) (2017), "Nigeria at a glance", available at: www.fao.org/ nigeria/fao-in-nigeria/nigeria-at-a-glance/en/ [23 June 2017].

FEWS NET (Famine Early Warning Systems Network) (2015), "The main harvest brings an end to the lean season in most areas across the country", available at: http://www.fews.net/westafrica/nigeria/food-security-outlook/october-2015 [19 June 2017]

FEWS NET (2016), "A Famine likely occurred in Bama LGA and may be ongoing in inaccessible areas of Borno State", available at: www.fews.net/west-africa/nigeria/special-report/ december-13-2016 [19 June 2017].

FEWS NET (2017a), "Global Price Watch", available at: www.fews.net/global/price-watch/june-2017 [19 June 2017].

FEWS NET (2017b), "Key Message Update, May 2017", available at: www.fews.net/west-africa/ nigeria/key-message-update/may-2017 [19 June 2017]. 
FEWS NET (2017c), "Nigeria | Famine Early Warning Systems Network", available at: www.fews.net/ west-africa/nigeria [25 June 2017].

FEWS NET (2017d), "Nigeria Special Report Archive", available at: https://www.fews.net/arch ive?f[0]=type\%3Areport\&f[1]=field_report_countries\%3A20\&f[2]=field_report_type\%3A51 [19 June 2017].

GADM (2015), "Global Administrative Areas”, database, http//www.gadm.org.

Guilbert, K. (2016), "Food shortages drive Nigeria's displaced from host families to camps", Thomson Reuters Foundation, March 23, available at: http://news.trust.org/ item/20160323132935-hf3pk/ [19 June 2017].

Haklay, M. and P. Weber. (2008), "OpenStreetMap: User-generated street maps”, IEEE Pervasive Computing, Vol. 7/4, pp. 12-18.

Martin, P. (2016), "Nigeria's Boko Haram crisis: 'We survived militants but face starvation'”, BBC, 2 December.

OCHA (Office for the Coordination of Humanitarian Affairs) (2017), "Nigeria Northeast: Humanitarian Overview (May 2017)”, OCHA, available at: http://fscluster.org/ne_nigeria/document/nigerianortheast-humanitarian-overview [19 June 2017].

Ogbozor, E. (2016), Resilience to Violent Extremism: The Rural Livelihood Coping Strategies in the Lake Chad Basin, available at: www.hicn.org/wordpress/wp-content/uploads/2012/06/HiCNWP-237.pdf [23 June 2017].

Raleigh, C., Linke, A., Hegre, H. and J. Karlsen (2010), "Introducing ACLED-Armed Conflict Location and Event Data", Journal of Peace Research, Vol. 47/5, pp. 651-660.

Skinner, J. and S. Begum (2016), Lake Chad's unseen crisis: Voices of refugees and internally displaced people from Niger and Nigeria, Oxfam International, pp. 1-20, available at: https:// www.oxfam.org/sites/www.oxfam.org/files/file attachments/bn-lake-chad-refugees-idps190816-en.pdf [19 June 2017].

Watts, M.J. (2013), Silent violence: Food, famine, and peasantry in northern Nigeria, Athens: University of Georgia Press.

WFP (World Food Program) (2017), "WFP Nigeria Situation Report \#15", WFP, available at: http:// fscluster.org/ne_nigeria/document/wfp-nigeria-situation-report-15 [25 June 2017]. 



\section{ALSO IN THE WEST AFRICAN PAPERS SERIES:}

Allen, T. and P. Heinrigs (2016), "Emerging Opportunities in the West African Food Economy", West African Papers, No. 1, OECD Publishing, Paris. http://dx.doi.org/10.1787/5jlvfj4968jb-en

Lewis, K. and C. Buontempo (2016), "Climate Impacts in the Sahel and West Africa: The Role of Climate Science in Policy Making", West African Papers, No. 2, OECD Publishing, Paris. http://dx.doi.org/10.1787/5jlsmktwjcd0-en

Gnisci, D. (2016), “Women's Roles in the West African Food System: Implications and Prospects for Food Security and Resilience", West African Papers, No. 3, OECD Publishing, Paris. http://dx.doi.org/10.1787/5jlpl4mh1hxn-en

Staatz, J. and F. Hollinger (2016), "West African Food Systems and Changing Consumer Demands", West African Papers, No.4, OECD Publishing, Paris. http://dx.doi.org/10.1787/b165522b-en

Prieto Curiel, R., P. Heinrigs and I. Heo (2017), "Cities and Spatial Interactions in West Africa: A Clustering Analysis of the Local Interactions of Urban Agglomerations", West African Papers, No. 5, OECD Publishing, Paris. http://dx.doi.org/10.1787/57b30601-en

Walther, O. (2017), "Cross-border Co-operation Networks in West Africa", West African Papers, No. 06, OECD Publishing, Paris. http://dx.doi.org/10.1787/73298292-en

Ibrahim, I.Y. (2017), “The Wave of Jihadist Insurgency in West Africa: Global Ideology, Local Context, Individual Motivations", West African Papers, No. 07, OECD Publishing, Paris. http://dx.doi.org/10.1787/eb95c0a9-en

Allen, T. (2017), "The cost of high food prices in West Africa", West African Papers, No. 08, OECD Publishing, Paris. http://dx.doi.org/10.1787/c2db143f-en

For more information on the series, please contact: lia.beyeler@oecd.org 